Article

\title{
Immobilized Luminescent Bacteria for the Detection of Mycotoxins under Discrete and Flow-Through Conditions
}

\author{
Olga Senko ${ }^{1,2}$, Nikolay Stepanov ${ }^{1,2}$, Olga Maslova $^{1}{ }^{1}$, Rashid Akhundov $^{1}$, Anvar Ismailov ${ }^{1}$ \\ and Elena Efremenko 1,2,*(D) \\ 1 Faculty of Chemistry, Lomonosov Moscow State University, 119991 Moscow, Russia; \\ senkoov@gmail.com (O.S.); na.stepanov@gmail.com (N.S.); olga.maslova.rabota@gmail.com (O.M.); \\ axundovrashid@gmail.com (R.A.); anvaris@list.ru (A.I.) \\ 2 Emanuel Institute of Biochemical Physics, Russian Academy of Science, 119334 Moscow, Russia \\ * Correspondence: elena_efremenko@list.ru; Tel.: +7-495-939-3170
}

Received: 24 April 2019; Accepted: 16 May 2019; Published: 20 May 2019

\begin{abstract}
A biosensitive element in the form of bacterial Photobacterium phosphoreum cells immobilized in poly(vinyl alcohol) cryogel was tested for the determination of different mycotoxins under discrete and flow-through analysis conditions. The immobilized bioluminescent cells made it possible to quantify the presence of Ochratoxin A, Sterigmatocystin, Zearalenone, and Deoxynivalenon in aqueous media in a wide range of their concentrations $(0.017-56 \mathrm{mg} / \mathrm{L}, 0.010-33 \mathrm{mg} / \mathrm{L}, 0.009-14 \mathrm{mg} / \mathrm{L}$, and 0.026-177 mg/L, respectively) via measuring the quenching of cell luminescence. The flow conditions allowed the analysis sensitivity to be improved by an order of magnitude in terms of detected concentrations. Using the immobilized luminescent bacterial cells, we have shown the possibility of evaluating the efficiency of the mycotoxins' hydrolysis under the action of enzymes. In this way, a $94 \pm 4.5 \%$ efficiency of Zearalenone hydrolysis with hexahistidine-containing organophosphorus hydrolase for $1 \mathrm{~h}$-long treatment of the mycotoxin solution $(100 \mathrm{mg} / \mathrm{L})$ was shown.
\end{abstract}

Keywords: bioluminescent bacteria; immobilized cells; mycotoxins; flow-through system; biosensitive element; analysis; hydrolysis

\section{Introduction}

The problem of the contamination of various agricultural raw materials and food by mycotoxins in the modern world is becoming increasingly alarming, since, along with the development and improvement of methods for detecting mycotoxins, information is accumulated about their presence in various analyzed objects. Advances in analytical chemistry concerning the detection of mycotoxins in various environments [1], together with the latest medical and biological studies of the effect of these toxins on the human body and animals [2], indicate a high risk of these natural compounds, especially for animals that are the object of agricultural production [3,4], as well as for the persons producing and consuming agricultural products [4]. The development of modern methods of analyzing food and animal feed for the presence of mycotoxins is currently focused on creating fast and reliable control methods that are easily adaptable for various conditions [5]. Rapid screening methods are recognized in the European Union as a strategic tool for solving problems associated with mycotoxin contamination [6].

In addition, new modes of mycotoxin destruction are being actively developed [7-9]. In order to intensify the search for effective approaches to the destruction of mycotoxins, it is necessary to use methods for quickly assessing their efficiency, which give a prompt and reliable analytical response. 
An analytical test based on the use of bioluminescent bacteria meets all of the above requirements. In particular, it is characterized by a quick response and the possibility of qualitative and quantitative analysis. Additionally, it is possible to adapt existing portable devices for its use [10,11]. An example is the commercial standardized Microtox system based on suspension bacteria Allivibrio fischeri (Vibrio fischeri) cells, which is currently used to determine the presence of a wide variety of eco-toxicants. However, other luminous bacteria have been described that can be successfully used for the same purpose [12]. Particular attention is paid to the use of biosensitive elements in the form of immobilized bioluminescent bacterial cells $[13,14]$. The immobilization of luminous bacterial cells makes it possible to use them under conditions in which the applicability of suspension cultures is limited, for example, in flow systems. The analysis of toxicants under flow conditions allows the minimum detectable concentrations of xenobiotics to be increased, reducing the analysis time by increasing the flow rate of the solution. In particular, this was previously shown for a biosensitive element developed on the basis of the bacterial Photobacterium phosphoreum cells immobilized in macroporous poly(vinyl alcohol) cryogel (PVA cryogel). It was found that such a biosensitive element can be successfully used for analyzing the toxicity of media containing heavy metal ions, phenol derivatives, and organophosphorous pesticides, both in a discrete and flow-through mode $[13,14]$. The PVA cryogel as a carrier positively influences the stability of the cell bioluminescent signal in the absence of toxins and does not affect the bioluminescent registration with the modern devices used in the experiments.

In general, PVA cryogel is a well-known nontoxic and chemically stable polymer matrix [15-17] successfully used for the immobilization of living cells of different microorganisms. It can be stored for a long time [18,19] and has been proven to be effective for various applications [20-23]. The immobilization of cells in the PVA cryogel can be achieved by the inclusion of the cells in the macroporous polymer matrix during the process of its cryoformation. The carrier matrix is formed owing to multiple intermolecular links between the polymer molecules: a lot of hydrogen bonds appear between the $\mathrm{OH}$-groups of the neighboring polymer chains [24], and the cells are accumulated inside the pores of the matrix. It is known that, in their suspended form, bacterial P. phosphoreum cells and several other strains can be used for determining the presence of micotoxins [25]. The spectrum of mycotoxins and the range of their concentrations that can be detected using bioluminescent bacterial cells are known from various scientific publications (Table 1) [25-31]. However, the possibility of using bioluminescent bacterial cells in an immobilized form for the analysis of mycotoxins has not been investigated so far.

The mechanism of the influence of various toxic compounds on the bioluminescence of bacterial Photobacterium phosphoreum cells depends on the chemical nature of these compounds, but the sensitivity of the toxins' determination essentially depends on the form of the cells used for the analysis (suspended or immobilized) [32]. Therefore, the purpose of this work was to assess the feasibility of using cells of bioluminescent bacteria P. phosphoreum immobilized in PVA cryogel for detecting several mycotoxins under discrete and flow-through conditions. In particular, it was also interesting to apply the immobilized cells of bioluminescent bacterial cells for evaluating the efficiency of mycotoxin hydrolysis under the action of enzymes. In this study, such an assessment was carried out for the hydrolysis of Zearalenone under the action of the enzyme hexahistidine organophosphorus hydrolase $\left(\mathrm{His}_{6}-\mathrm{OPH}\right)$.

Below, we list the novel features of this investigation compared to our previous studies on using photobacterial cells immobilized in PVA cryogel as a biosensitive element: (i) new substances such as mycotoxins were analyzed in this work. In particular, the detection of Sterigmatocystin was investigated by the bioluminescent method with photobacterial cells for the first time; (ii) the detection of mycotoxins in the flow-through regime of functioning of the biosensing apparatus was demonstrated for the first time, and the sensitivity of the detection, as well as duration of analysis, were improved under the flow conditions of analysis; and iii) the evaluation of the efficiency of mycotoxin hydrolysis as a result of enzyme action was performed using immobilized bioluminescent bacterial cells for the first time. 
Table 1. The use of suspension cells of bioluminescent bacteria for the determination of different mycotoxins in a discrete mode of analysis.

\begin{tabular}{ccc}
\hline Mycotoxin & Cells [Reference] & Limits of Detection (mg/L) \\
\hline Aflatoxin B1 & Aliivibrio fischeri [16] & $1-17.1$ \\
& P. phosphoreum [15] & $3.6-25$ \\
Vitrinin & V. fischeri (Microtox) [17] & $0.005-2.98$ \\
& P. phosphoreum [15] & $7.00-20.0$ \\
Deoxynivalenol & V. qinghaiensis sp. [18] & $5-12$ \\
Fumonisin B1 & V. qinghaiensis sp. [18] & $5-30$ \\
Fusaric acid & V. qinghaiensis sp. [18] & $5-15$ \\
Ochratoxin A & V. qinghaiensis sp. [19] & $5-40$ \\
& V. harveyi [20] & $0.0001-0.001$ \\
Patulin & P. phosphoreum [15] & $12.5-17.0$ \\
& V. qinghaiensis sp. [18] & $5-11$ \\
Penicillic acid & P. phosphoreum [15] & \\
PR-toxin & V. qinghaiensis sp. [18] & $5-13$ \\
Rubratoxin B & P. phosphoreum [15] & $3.14-10.7$ \\
T-2 & P. phosphoreum [15] & $0.9-4.2$ \\
& P. phosphoreum [15] & $19.69-33$ \\
Zearalenone & P. phosphorum Sq3 [21] & 12 \\
& V. fischeri F1 [21] & 12 \\
& V. qinghaiensis sp. [18] & $5-10$ \\
\hline & P. phosphoreum [15] & $9.35-13.5$ \\
\hline
\end{tabular}

\section{Materials and Methods}

\subsection{Materials}

Mycotoxins (Ochratoxin A, Sterigmatocystin, Zearalenone, and Deoxynivalenon) were purchased from Sigma-Aldrich to carry out this investigation. For the experiments, concentrated solutions of mycotoxins in methanol were preliminarily prepared. Solutions of mycotoxins of the required concentration were prepared by diluting the original stock solutions of mycotoxins in methanol. In the analysis, the quenching of the bioluminescence of the immobilized luminous bacteria under the action of the methanol present in the reaction medium was taken into account.

$\mathrm{Na}_{2} \mathrm{HPO}_{4}, \mathrm{KH}_{2} \mathrm{PO}_{4} \times 2 \mathrm{H}_{2} \mathrm{O},\left(\mathrm{NH}_{4}\right)_{2} \mathrm{HPO}_{4}, \mathrm{~Pb}\left(\mathrm{NO}_{3}\right)_{2}, \mathrm{CuSO}_{4} \times 5 \mathrm{H}_{2} \mathrm{O}, \mathrm{ZnSO}_{4} \times 7 \mathrm{H}_{2} \mathrm{O}$, glycerol, $\mathrm{MgSO}_{4} \times 7 \mathrm{H}_{2} \mathrm{O}, \mathrm{NaCl}$, and $\mathrm{HgCl}_{2}$ were purchased from Chimmed (Moscow, Russia); peptone and yeast extract were purchased from Difco (Becton, Dickinson and Company, Franklin Lakes, NJ, USA); and poly(vinyl alcohol) 16/1 (M.w. $84 \mathrm{kDa}$ ) was purchased from Sinopec Corp (Beijing, China). Photobacterium phosphoreum B-1717 was purchased from the All-Russian Collection of Industrial Microorganisms (http://www.genetika.ru/vkpm/).

\subsection{Culture and Growth Conditions}

P. phosphoreum cells were grown and maintained in a submerged culture at $18^{\circ} \mathrm{C}$ under agitation at $60 \mathrm{rpm}$ (IRC-1-U temperature-controlled shaker, Adolf Kuhner AG Apparatebau, Switzerland). The composition of the Farghaly growth medium (g/L distilled water) was as follows: $\mathrm{NaCl}: 30.0 ; \mathrm{Na}_{2} \mathrm{HPO}_{4}$ : 5.3; $\mathrm{KH}_{2} \mathrm{PO}_{4} \times 2 \mathrm{H}_{2} \mathrm{O}: 2.1 ;\left(\mathrm{NH}_{4}\right)_{2} \mathrm{HPO}_{4}: 0.5 ; \mathrm{MgSO}_{4} \times 7 \mathrm{H}_{2} \mathrm{O}: 0.1$; yeast extract: 1.0 ; peptone: 5.0 ; glycerol: 3.0. The cell concentration in the growing culture was determined by spectrophotometry. To convert the cell densities into the biomass concentration, the calibration curve for optical density vs. dry cell weight was used. The optical density of the culture medium was determined by spectrophotometry (Agilent UV-853 spectrophotometer, Agilent Technologies, Waldbronn, Germany) at the wavelength of $660 \mathrm{~nm}$, and the cells were cultivated for $22 \mathrm{~h}$ to an optical density of $0.75 \pm 0.05$, separated from the culture medium by centrifugation (5000 rpm, 15 min., J2 21 centrifuge, Beckman, Brea, CA, USA), and afterwards used in the immobilization procedure. The procedure for immobilizing the bioluminescent cells in PVA cryogel was described previously [14]. To prepare the samples of immobilized cells, 
the cell biomass precipitate (with a moisture content of $78 \pm 2 \%$ ) obtained after centrifugation of the cell broth was thoroughly mixed with a $10 \%(w / v)$ aqueous PVA solution to obtain a $10 \%(w / w)$ concentration of bacterial cells. This mixture was pipetted into $96-$ well microplates $(0.2 \mathrm{~mL} /$ well $)$, which were placed in a freezer at $-20^{\circ} \mathrm{C}$ for $24 \mathrm{~h}$ and then thawed at $+4{ }^{\circ} \mathrm{C}$. The cylinder granules of PVA cryogel $(\mathrm{d}=6.6 \pm 0.1 \mathrm{~mm}, \mathrm{~h}=4.9 \pm 0.1 \mathrm{~mm})$ formed in this way contained cells immobilized by inclusion. The average wet weight of one granule was $0.17 \pm 0.001 \mathrm{~g}$.

\subsection{Luminescence Measurements}

Bioluminescence of immobilized bacteria was analyzed using both a 1250 LKB-Wallac luminometer (LKB Wallac, Turku, Finland) and 3560 microluminometer (New Horizons Diagnostics Co, Columbia, $\mathrm{MD}, \mathrm{USA}$ ). Bioluminescence detection was performed in aqueous media based on a $2 \% \mathrm{NaCl}$ solution at $10 \pm 1{ }^{\circ} \mathrm{C}$. The maximum level of luminescence $\left(\mathrm{I}_{0}\right)$ was determined for $10 \mathrm{~s}$ at $10^{\circ} \mathrm{C}$ after thermal equilibration of the flow-through system. The tests were performed in triplicate. For practical purposes, the residual intensity of bioluminescence was used $\left(\mathrm{I} / \mathrm{I}_{0}\right)$, which was expressed as a percentage of the baseline signal $\left(\mathrm{I}_{0}\right)$. The residual intensity of bioluminescence $\left(\mathrm{I} / \mathrm{I}_{0}\right)$ was analyzed in a discrete test after the exposure of the cells to a certain mycotoxin for $0.5 \mathrm{~h}$ after its addition to medium containing the biosensitive element.

With the requirements of the present-day quick monitoring in mind, we assembled a biosensing apparatus to detect the mycotoxins in aqueous media in a flow-through regime. Photobacteria immobilized in PVA cryogel were used as a sensitive element in this biosensing apparatus, which was described in detail previously $[13,14]$. The principal setup of the biosensing apparatus for detecting mycotoxins in flow-through aqueous systems using immobilized photobacterial was as follows. To evaluate the presence of a certain mycotoxin, the sample of luminescent cells immobilized in PVA cryogel (1 granule) was placed into the analytical cell (flow cuvette of a 1250 LKB-Wallac luminometer (Turku, Finland) filled with $2 \% \mathrm{NaCl}$ solution and localized in the thermostatted chamber of the device. Previously thermostatted $\left(+10 \pm 1{ }^{\circ} \mathrm{C}\right)$ sample solution containing the mycotoxin to be analyzed was pumped from a separate container with a velocity of $90 \mathrm{~mL} / \mathrm{h}$ controlled by a peristaltic recycling pump (Masterflex Easy-Load II L/S, model 77200-50, Cole Parmer, Barrington, IL, USA) through the analytical cell $(2 \mathrm{~mL})$ for a certain time $(10 \mathrm{~min})$ to ensure contact of the solution with the immobilized photobacteria, and the effluent was collected in a trash container. The bioluminescent signal was permanently registered with a computer system. The data obtained (the initial and the residual levels of bioluminescence) were used to construct a graph the concentration dependencies of the luminescent cells' characteristics for various mycotoxins. Thus, the range of detectable concentrations of mycotoxins was analyzed under the following conditions: flow medium $-2 \% \mathrm{NaCl}$; flow rate $-90 \mathrm{~mL} / \mathrm{h}$; analysis duration-10 $\mathrm{min}$; temperature- $+10 \pm 1{ }^{\circ} \mathrm{C}$.

\subsection{Hydrolysis of Zearalenone Under the Action of the Enzyme His ${ }_{6}-\mathrm{OPH}$}

For the experiment, a $100 \mathrm{mg} / \mathrm{L}$ solution of Zearalenone in methanol and a solution of the His $_{6}-\mathrm{OPH}(0.1 \mathrm{mg} / \mathrm{mL})$ in $0.1 \mathrm{M}$ phosphate buffer ( $\left.\mathrm{pH} 7.4\right)$ with an activity of $200 \mathrm{U} / \mathrm{mL}$ were used at room temperature. The procedure for enzyme production and purification was detailed in a previous paper [33]. The activity of $\mathrm{His}_{6}-\mathrm{OPH}$ was determined as described previously [34], with $7.8 \mathrm{mM}$ aqueous Paraoxon stock solution at $405 \mathrm{~nm}$ using the Agilent 8453 UV-visible spectroscopy system (Agilent Technology, Waldbronn, Germany) equipped with a thermostatted analytical cell. The initial concentration of Zearalenone in the reaction medium was $65 \pm 3 \mathrm{mg} / \mathrm{L}$. The initial toxicity of this solution was evaluated under the conditions indicated above. The treatment of the mycotoxin was carried out for $1 \mathrm{~h}$ at room temperature without agitation, and the residual toxicity of the obtained solution was verified using immobilized luminescent cells in a discrete mode of analysis. 


\subsection{Evaluation of Zearalenone Hydrolysis by the Enzyme-Linked Immunosorbent Assay (ELISA) Test Kit}

Analyses were carried out using the MaxSignal ${ }^{\circledR}$ Zearalenone ELISA Test Kit (Bioo Scientific Corp, Austin, TX, USA) with a sensitivity of $0.3 \mathrm{ng} / \mathrm{mL}$. Samples were prepared according to the instructions provided by the manufacturers of the ELISA kits. The optical density was measured at $450 \mathrm{~nm}$ using the microplate reader iMark (Bio-Rad Laboratories, Inc., Hercules, CA, USA) at room temperature. All the measurements were repeated three times, and the results were analyzed with the Microplate Manager ${ }^{\circledR}$ 6, version 6.3.

\section{Results}

\subsection{The Use of a Biosensitive Element for the Determination of Mycotoxins in Aqueous Solutions}

The linear ranges of detection of various mycotoxins were determined using P. phosphoreum cells immobilized in PVA cryogel (Figure 1). The dependences shown in Figure 1 and the equations describing them (Table 2) can be considered as gauge graphs.
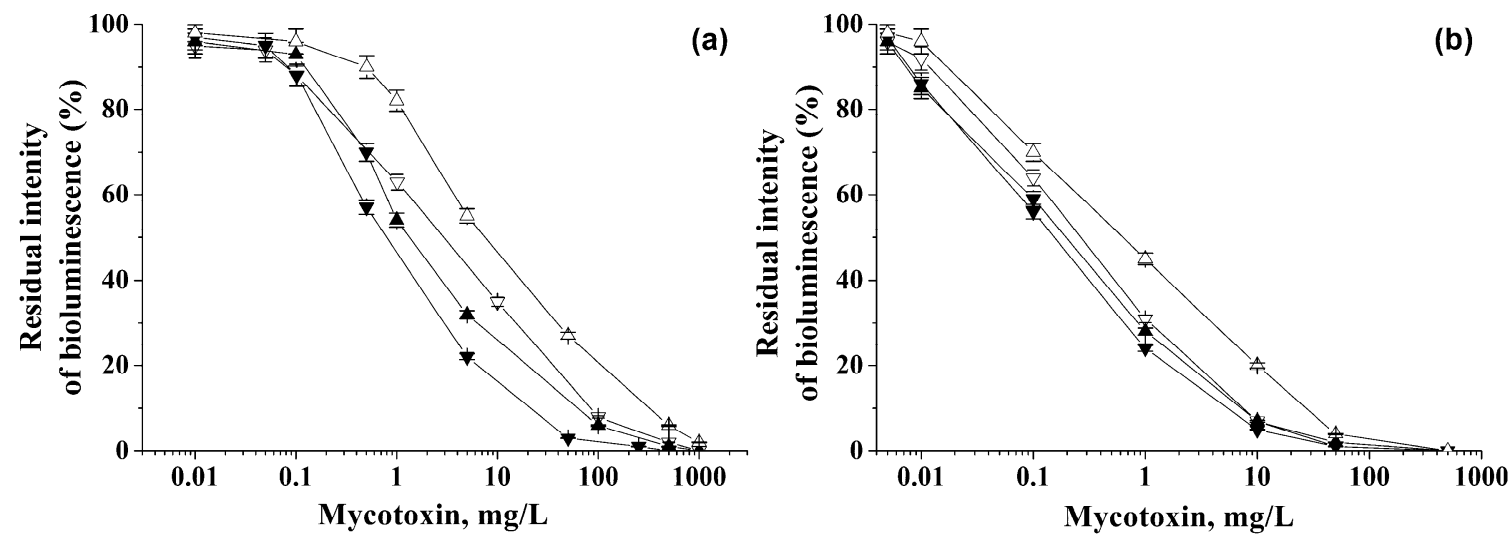

Figure 1. Residual intensity of bioluminescence of immobilized cells in the presence of various mycotoxins: $(\nabla)$ Ochratoxin A, $(\mathbf{\Lambda})$ Deoxynivalenol, $(\mathbf{v})$ Sterigmatocystin, and $(\Delta)$ Zearalenone. Analysis was carried out under discrete (a) and flow-through (b) conditions.

Table 2. The results of mycotoxins' analysis in discrete and flow-through regimes carried out using immobilized cells of bioluminescent bacteria P. phosphoreum.

\begin{tabular}{|c|c|c|c|c|}
\hline \multirow{2}{*}{ Mycotoxin } & \multicolumn{2}{|c|}{ Discrete Analysis (30 min) } & \multicolumn{2}{|c|}{ Flow-Through Analysis (10 min) } \\
\hline & ${ }^{1}$ The Equation; $\mathbf{R}^{2}$ & $\begin{array}{c}\text { Working Range, } \\
\mathrm{mg} / \mathrm{L}\end{array}$ & The Equation; $\mathbf{R}^{2}$ & $\begin{array}{c}\text { Working Range, } \\
\mathrm{mg} / \mathrm{L}\end{array}$ \\
\hline Ochratoxin A & $\begin{array}{c}y=-26.87 x+62.02 \\
R^{2}=0.99\end{array}$ & $0.14-56$ & $\begin{array}{c}y=-28.80 x+34.10 \\
R^{2}=0.99\end{array}$ & $0.017-4.6$ \\
\hline Deoxynivalenol & $\begin{array}{c}y=-29.10 x+59.14 \\
R^{2}=0.98\end{array}$ & $0.13-33$ & $\begin{array}{c}y=-26.50 x+31.50 \\
R^{2}=0.99\end{array}$ & $0.010-4.2$ \\
\hline Sterigmatocystin & $\begin{array}{c}y=-31.61 x+51.27 \\
R^{2}=0.98\end{array}$ & $0.09-14$ & $\begin{array}{c}y=-27.50 x+29.00 \\
R^{2}=0.98\end{array}$ & $0.009-3.2$ \\
\hline Zearalenone & $\begin{array}{c}y=-28.63 x+79.49 \\
R^{2}=0.98\end{array}$ & $0.64-177$ & $\begin{array}{c}y=-24.93 x+45.50 \\
R^{2}=0.99\end{array}$ & $0.026-16.7$ \\
\hline
\end{tabular}

\footnotetext{
${ }^{1}$ The equations describing the calibration dependencies presented in Figure 1, for the determination of mycotoxins in discrete and flow modes of analysis using immobilized cells of $P$. phosphoreum. $\mathrm{R}^{2}$ is the adjusted coefficient of determination.
}

As a result of the experiments, the lower limits of mycotoxin detection were established (Table 2), and the linear ranges were found for determining the mycotoxin concentrations using P. phosphoreum cells immobilized in PVA cryogel (Figure 1, Table 2). 
For the flow mode, the sensitivity of mycotoxin detection turned out to be higher by a factor of 8.2-25 compared to the discrete variant. Therefore, much lower concentrations of all the tested mycotoxins were found to be detectable in the flow regime of analysis.

As it follows from the data obtained, immobilized cells of P. phosphoreum in discrete and flow-through modes of analysis make it possible to accurately determine the presence of mycotoxins in solutions in a wide range of concentrations with a high sensitivity.

At the same time, the detection ranges of mycotoxin concentrations under flow conditions by the use of P. phosphoreum cells immobilized in PVA cryogel were 1.5 orders of magnitude wider than the similar ranges established for the same immobilized cells during the discrete analysis. Additionally, these ranges were shifted towards lower concentrations.

\subsection{Biosensitive Element in Assessment of Toxicity of the Reaction Medium Obtained after Hydrolysis of Zearalenone by $\mathrm{His}_{6}-\mathrm{OPH}$}

In this work, P. phosphoreum cells immobilized in PVA cryogel were used to evaluate the concentration of Zearalenone in the reaction medium before and after its hydrolytic treatment with $\mathrm{His}_{6}-\mathrm{OPH}$, which has lactonase activity $[23,24]$. As a control method for the determination of Zearalenone, an ELISA method was used. It has been confirmed that the $\mathrm{His}_{6}$-OPH enzyme effectively degrades Zearalenone. After $1 \mathrm{~h}$, the enzymatic destruction degree of this mycotoxin in the presence of $\mathrm{His}_{6}-\mathrm{OPH}$ was $94 \pm 4.5 \%$, and the concentration of this mycotoxin decreased from $65 \pm 3 \mathrm{mg} / \mathrm{L}$ to $3.9 \pm 0.2 \mathrm{mg} / \mathrm{L}$. The nonspecific chemical hydrolysis was accounted for when the obtained result was analyzed.

The results of assessing the concentration of Zearalenone using P. phosphoreum bacterial cells immobilized in PVA cryogel were in very good agreement with the data obtained using the ELISA method. According to the ELISA method, after $1 \mathrm{~h}$, the concentration of this mycotoxin in the presence of $\mathrm{His}_{6}$-OPH decreased from $65 \pm 3 \mathrm{mg} / \mathrm{L}$ to $4.1 \pm 0.2 \mathrm{mg} / \mathrm{L}$.

\section{Discussion}

According to the data obtained for P. phosphoreum cells immobilized in PVA cryogel, the immobilized photobacterial cells in the discrete mode of analysis allow concentrations of mycotoxins to be detected in a range different from that characteristic of the suspended cells (Tables 1 and 2).

Therefore, when using the immobilized cells (Table 2) for Zearalenone determination, the lower detection limit was 14.6 times lower, and the upper limit was 13.1 times higher, than in the case of free P. phosphoreum cells (Table 1). A similar trend was also observed for Ochratoxin A. Therefore, the application of immobilized cells made it possible to extend the working range of bioluminescent bacteria for the analysis of mycotoxins. In this way, the effectiveness of P. phosphoreum cells in an immobilized form for the analysis of mycotoxins was demonstrated in this study.

In addition, for Ochratoxin A and Zearalenone, it was shown that the concentration ranges for mycotoxin detection in the case of immobilized P. phosphoreum cells used in this investigation were wider than both of those known for other bioluminescent bacteria, and those established for the same luminous bacteria P. phosphoreum when used in suspension form to detect these two mycotoxins (Tables 1 and 2).

We consider the results obtained for using the immobilized cells for mycotoxin analysis in a flow-through regime to be of great practical importance. The detection of mycotoxins at lower concentrations with this technique than in the discrete mode can be due to the following. The standard application of bioluminescent bacterial cells for the determination of various ecotoxicants' presence, as a rule, consists of exposure of the cells in a solution of toxicants for $0.5 \mathrm{~h}$ to achieve an equilibrium state [13]. The analysis in flow mode allows the analyzed solution to be forcefully injected into the matrix of the cell carrier, and thus, ensures contact with the immobilized cells for all the mycotoxin molecules present in the analyzed sample. Therefore, the sensitivity of the bioluminescent method can be improved. 
The macroporous structure of the carrier matrix used makes it possible to vary the velocity of the mycotoxin solution flow through the analytical cell over a rather wide range with immobilized cells $[13,14]$. The choice of the PVA cryogel as the cell carrier allows flow velocities up to $180 \mathrm{~mL} / \mathrm{h}$ without problems (i.e., changing the characteristics) for the cells and polymer matrix itself. In this investigation, we used the velocity $90 \mathrm{~mL} / \mathrm{h}$; however, the applied biosensitive element can be potentially used for the analysis of toxicants at much higher flow rates (up to $180 \mathrm{~mL} / \mathrm{h}$ ) [13]. This is a fundamental difference between the biosensitive element used in this work and the known analytical systems based on suspension cells of bioluminescent bacteria. Therefore, it is possible to increase the rate of flow and thereby essentially reduce the time necessary for the analysis.

For practical use, it is important that the immobilized cells allow the quick detection of ecotoxicants present in the flow-through aqueous system in minimal concentrations. To quantify the applicability range of this technique, lower detection limits were determined for various mycotoxins, and calibration equations are given in Table 2. If it is known that only one mycotoxin is present in the sample, then it is possible to accurately determine its concentration.

It is known that $\mathrm{His}_{6}-\mathrm{OPH}$ can hydrolyze organophosphorus pesticides and mycotoxins [34-38]. The use of $\mathrm{His}_{6}-\mathrm{OPH}$, which exhibits lactonase activity with an extended substrate spectrum of action in comparison with natural lactonases [35], also guarantees the possibility of biological neutralization of various mycotoxins containing a lactone ring. Zearalenone has a lactone cycle in its structure, and can thus be considered as a potential substrate for the $\mathrm{His}_{6}-\mathrm{OPH}$ enzyme, which exhibits lactonase activity.

It was recently shown that immobilized P. phosphoreum cells can be used for the operational control of the presence of organophosphorus pesticides in the analyzed samples taken from different objects [13]. Our results show the possibility of using immobilized bioluminescent $P$. phosphoreum cells to control the content of mycotoxins and organophosphorus compounds in analytical samples before and after using the enzymes with various catalytic activities, such as $\mathrm{His}_{6}-\mathrm{OPH}$. These results can be useful to researchers engaged in the development of effective methods for the decomposition of toxins of different natures and analytical systems necessary for monitoring the effectiveness of the biological agents applied to decompose these toxins.

\section{Conclusions}

As a result of the study, it was found that $P$. phosphoreum cells immobilized in PVA cryogel can be effectively used to determine the concentration of mycotoxins, such as Ochratoxin A, Deoxynivalenol, Sterigmatocystin, and Zearalenone, in aqueous solutions in both discrete and flow-through modes of analysis. Note that the detection of Sterigmatocystin using bioluminescent bacteria has not been demonstrated previously, and the results obtained in the study of this mycotoxin are absolutely new. As compared with the discrete mode, which usually takes $30 \mathrm{~min}$, in the flow mode, which can only be implemented with the immobilized form of bioluminescent cells, it is possible to determine lower levels of mycotoxins within $10 \mathrm{~min}$ of analysis, representing a technique that is at least three times faster. The existing potential in the use of immobilized bioluminescent cells for the determination of mycotoxins has been successfully demonstrated in evaluating the enzymatic hydrolysis of Zearalenone under the action of the enzyme $\mathrm{His}_{6}-\mathrm{OPH}$.

\section{Patents}

RU Patent \#2394910 Luminescent biocatalyst for the determination of toxicants.

Author Contributions: Conceptualization and methodology, E.E. and I.A., formal analysis, N.S. and O.M.; investigation, O.S., N.S., and A.R.; supervision, E.E.; writing-original draft O.S. and O.M.; writing-review \& editing, E.E.

Funding: This research was funded by the Russian Science Foundation, grant number 16-14-00061.

Conflicts of Interest: The authors declare no conflict of interest. 


\section{References}

1. Peltomaa, R.; Benito-Peña, E.; Moreno-Bondi, M.C. Bioinspired Recognition Elements for Mycotoxin Sensors. Anal. Bioanal. Chem. 2018, 410, 747-771. [CrossRef]

2. Yin, S.; Liu, X.; Fan, L.; Hu, H. Mechanisms of Cell Death Induction by Food-Borne Mycotoxins. Crit. Rev. Food Sci. Nutr. 2018, 58, 1406-1417. [CrossRef]

3. Lumsangkul, C.; Chiang, H.I.; Lo, N.W.; Fan, Y.K.; Ju, J.C. Developmental Toxicity of Mycotoxin Fumonisin B1 in Animal Embryogenesis: An Overview. Toxins 2019, 11, 114. [CrossRef]

4. Viegas, S.; Assunção, R.; Martins, C.; Nunes, C.; Osteresch, B.; Twarużek, M.; Kosicki, R.; Grajewski, J.; Ribeiro, E.; Viegas, C. Occupational Exposure to Mycotoxins in Swine Production: Environmental and Biological Monitoring Approaches. Toxins 2019, 11, 78. [CrossRef]

5. Evtugyn, G.; Hianik, T. Electrochemical Immuno-and Aptasensors for Mycotoxin Determination. Chemosensors 2019, 7, 10. [CrossRef]

6. Lattanzio, V.M.; Von Holst, C.; Lippolis, V.; De Girolamo, A.; Logrieco, A.F.; Mol, H.G.; Pascale, M. Evaluation of Mycotoxin Screening Tests in a Verification Study Involving First Time Users. Toxins 2019, 11, 129. [CrossRef]

7. Wang, H.; Mao, J.; Zhang, Z.; Zhang, Q.; Zhang, L.; Li, P. Photocatalytic Degradation of Deoxynivalenol over Dendritic-Like $\alpha-\mathrm{Fe}_{2} \mathrm{O}_{3}$ under Visible Light Irradiation. Toxins 2019, 11, 105. [CrossRef] [PubMed]

8. Huang, W.; Chang, J.; Wang, P.; Liu, C.; Yin, Q.; Song, A.; Gao, T.; Dang, X.; Lu, F. Effect of Compound Probiotics and Mycotoxin Degradation Enzymes on Alleviating Cytotoxicity of Swine Jejunal Epithelial Cells Induced by Aflatoxin B1 and Zearalenone. Toxins 2019, 11, 12. [CrossRef] [PubMed]

9. Quiles, J.M.; Nazareth, T.D.M.; Luz, C.; Luciano, F.B.; Mañes, J.; Meca, G. Development of an Antifungal and Antimycotoxigenic Device Containing Allyl Isothiocyanate for Silo Fumigation. Toxins 2019, 11, 137. [CrossRef]

10. Michelini, E.; Cevenini, L.; Calabretta, M.M.; Spinozzi, S.; Camborata, C.; Roda, A. Field-Deployable Whole-Cell Bioluminescent Biosensors: So Near and yet so far. Anal. Bioanal. Chem. 2013, 405, 6155-6163. [CrossRef]

11. Roggo, C.; Van Der Meer, J.R. Miniaturized and Integrated Whole Cell Living Bacterial Sensors in Field Applicable Autonomous Devices. Curr. Opin. Biotechnol. 2017, 45, 24-33. [CrossRef]

12. Briscoe, S.F.; Cai, J.; DuBow, M.S. Luminescent Bacterial Biosensors for the Rapid Detection of Toxicants. In Book Microscale testing in aquatic toxicology; Wells, P.G., Lee, K., Blaise, C., Eds.; CRC Press: Boca Raton, FL, USA, 2018; pp. 161-170.

13. Efremenko, E.N.; Maslova, O.V.; Kholstov, A.V.; Senko, O.V.; Ismailov, A.D. Biosensitive Element in the form of Immobilized Luminescent Photobacteria for Detecting Ecotoxicants in Aqueous Flow-Through Systems. Luminescence 2016, 31, 1283-1289. [CrossRef] [PubMed]

14. Efremenko, E.N.; Senko, O.V.; Aleskerova, L.E.; Alenina, K.A.; Mazhul, M.M.; Ismailov, A.D. Biosensors Based on the Luminous Bacteria Photobaterium Phosphoreum Immobilized in Polyvinyl Alcohol Cryogel for the Monitoring of Ecotoxicants. Appl. Biochem. Microbiol. 2014, 50, 477-482. [CrossRef]

15. Lozinsky, V.I. Polymeric Cryogels as a New Family of Macroporous and Supermacroporous Materials for Biotechnological Purposes. Russ. Chem. Bull. 2008, 57, 1015-1032. [CrossRef]

16. Lozinsky, V.I. A Brief History of Polymeric Cryogels. In Polymeric Cryogels; Okay, O., Ed.; Springer: Berlin, Germany, 2014; pp. 1-48.

17. Kumar, A. Supermacroporous Cryogels; CRC Press: Boca Raton, FL, USA, 2016; pp. 1-496.

18. Efremenko, E.N.; Tatarinova, N.Y. The Effect of Long-Term Preservation of Bacterial Cells Immobilized in Poly(Vinyl Alcohol) Cryogel on their Viability and Biosynthesis of Target Metabolites. Microbiology 2007, 76, 336-341. [CrossRef]

19. Senko, O.; Gladchenko, M.; Maslova, O.; Efremenko, E. Long-Term Storage and Use of Artificially Immobilized Anaerobic Sludge as a Powerful Biocatalyst for Conversion of Various Wastes Including Those Containing Xenobiotics to Biogas. Catalysts 2019, 9, 326. [CrossRef]

20. Efremenko, E.N.; Nikolskaya, A.B.; Lyagin, I.V.; Senko, O.V.; Makhlis, T.A.; Stepanov, N.A.; Maslova, O.V.; Mamedova, F.; Varfolomeev, S.D. Production of Biofuels from Pretreated Microalgae Biomass by Anaerobic Fermentation with Immobilized Clostridium acetobutylicum cells. Bioresour. Technol. 2012, 114, 342-348. [CrossRef] 
21. Maslova, O.; Stepanov, N.; Senko, O.; Efremenko, E. Production of Various Organic Acids from Different Renewable Sources by Immobilized Cells in the Regimes of Separate Hydrolysis and Fermentation (SHF) and Simultaneous Saccharification and Fermentation (SFF). Bioresour. Technol. 2019, 272, 1-9. [CrossRef]

22. Maslova, O.V.; Sen'ko, O.V.; Stepanov, N.A.; Efremenko, E.N. Lactic Acid Production Using Free Cells of Bacteria and Filamentous Fungi and Cells Immobilized in Polyvinyl Alcohol Cryogel: A Comparative Analysis of the Characteristics of Biocatalysts and Processes. Catal. Ind. 2016, 8, 280-285. [CrossRef]

23. Stepanov, N.; Efremenko, E. “Deceived” Concentrated Immobilized Cells as Biocatalyst for Intensive Bacterial Cellulose Production from Various Sources. Catalysts 2018, 8, 33. [CrossRef]

24. Lozinsky, V.I.; Zubov, A.L.; Titova, E.F. Poly(Vinyl Alcohol) Cryogels Employed as Matrices for Cell Immobilization. 2. Entrapped Cells Resemble Porous Fillers in Their Effects on the Properties of PVA-Cryogel Carrier. Enzym. Microb. Technol. 1997, 20, 182-190. [CrossRef]

25. Yates, I.E.; Porter, J.K. Bacterial Bioluminescence as a Bioassay for Mycotoxins. Appl. Environ. Microbiol. 1982, 44, 1072-1075.

26. Krifaton, C.; Kriszt, B.; Szoboszlay, S.; Cserháti, M.; Szúcs, Á.; Kukolya, J. Analysis of Aflatoxin-B1-Degrading Microbes by Use of a Combined Toxicity-Profiling Method. Mutat. Res. Genet. Toxicol. Environ. Mutagen. 2011, 726, 1-7. [CrossRef]

27. Santacroce, M.P.; Narracci, M.; Acquaviva, M.I.; Zacchino, V.; Lo Noce, R.; Centoducati, G.; Cavallo, R.A. Effects Induced in Vitro by Aflatoxin B1 on Vibrio Fischeri and Primary Cultures of Sparus Aurata Hepatocytes. Chem. Ecol. 2011, 27, 67-76. [CrossRef]

28. Jian, Q.; Gong, L.; Li, T.; Wang, Y.; Wu, Y.; Chen, F.; Qu, H.; Duan, X.; Jiang, Y. Rapid Assessment of the Toxicity of Fungal Compounds Using Luminescent Vibrio Qinghaiensis Sp. q67. Toxins 2017, 9, 335. [CrossRef]

29. Li, J.; Jiang, G.; Yang, B.; Dong, X.; Feng, L.; Lin, S.; Chen, F.; Ashraf, M.; Jiang, Y. A Luminescent Bacterium Assay of Fusaric Acid Produced by Fusarium Proliferatum from Banana. Anal. Bioanal. Chem. 2012, 402, 1347-1354. [CrossRef]

30. Wang, W.; Zhang, M.; Fang, J.; Zhang, L.; Zou, X.; Wang, X. Improved Detection of Ochratoxin A by Marine Bioluminescent Bacteria V. harveyi BA. Czech J. Food Sci. 2013, 31, 88-93. [CrossRef]

31. Katsev, A.M.; Goŭster, O.S.; Starodub, N.F. Effect of Mycotoxin T-2 on Bioluminescence Intensity of Bacteria. Ukr. Biokhim. Zh. 1999, 75, 99-103.

32. Prof., E.N.; Efremenko, M. (Eds.) Immobilized Cells: Biocatalysts and Processes: Monograph; RIOR: Russia, 2018; pp. 1-500. [CrossRef]

33. Efremenko, E.; Votchitseva, Y.; Plieva, F.; Galaev, I.; Mattiasson, B. Purification of His 6 -Organophosphate Hydrolase Using Monolithic Supermacroporous Polyacrylamide Cryogels Developed for Immobilized Metal Affinity Chromatography. Appl. Microbiol. Biotechnol. 2006, 70, 558-563. [CrossRef]

34. Votchitseva, Y.A.; Efremenko, E.N.; Aliev, T.K.; Varfolomeyev, S.D. Properties of Hexahistidine-Tagged Organophosphate Hydrolase. Biochemistry (Moscow) 2006, 71, 167-172. [CrossRef]

35. Sirotkina, M.S.; Efremenko, E.N. Rhodococcus Lactonase with Organophosphate Hydrolase (OPH) Activity and $\mathrm{His}_{6}$-Tagged OPH with Lactonase Activity: Evolutionary Proximity of the Enzymes and New Possibilities in Their Application. Appl. Microb. Biotech. 2014, 98, 2647-2656. [CrossRef]

36. Efremenko, E.N.; Lyagin, I.V.; Aslanly, A.G.; Makhlis, T.A. The Method of Biodegradation of Micotoxins. RU Patent 2634914, 8 November 2017.

37. Maslova, O.V.; Senko, O.V.; Efremenko, E.N. The Influence of Enzymatic Removal of Chlorpyrifos from Feed Grain Mixes on Biochemical Parameters of Rat Blood. Biochem. (Mosc.) Ser. B 2018, 12, 181-185. [CrossRef]

38. Senko, O.; Maslova, O.; Efremenko, E. Optimization of the Use of His 6 -OPH-Based Enzymatic Biocatalysts for the Destruction of Chlorpyrifos in Soil. Int. J. Environ. Res. Public Health 2017, 14, 1438. [CrossRef]

(C) 2019 by the authors. Licensee MDPI, Basel, Switzerland. This article is an open access article distributed under the terms and conditions of the Creative Commons Attribution (CC BY) license (http://creativecommons.org/licenses/by/4.0/). 